\title{
Landscape enhancement of floral resources for honey bees in agro-ecosystems*
}

\author{
Axel DeCOURTYE $^{1}$, Eric MADER ${ }^{2,3}$, Nicolas DESNEUX $^{4 *}$ \\ ${ }^{1}$ ACTA, UMT PrADE, UMR 406, Site Agroparc, 84914 Avignon Cedex 9, France \\ ${ }^{2}$ The Xerces Society for Invertebrate Conservation, 4828 Southeast Hawthorne Boulevard, Portland, \\ OR 97215, USA \\ ${ }^{3}$ Department of Entomology, University of Minnesota, 1980 Folwell Avenue, Saint Paul, MN 55108, USA \\ ${ }^{4}$ Unité de Recherches Intégrées en Horticulture, INRA, 400 route des Chappes, 06903 Sophia-Antipolis, France
}

Received 26 September 2009 - Revised 28 February 2010 - Accepted 1st March 2010

\begin{abstract}
Honey bee populations have experienced serious losses in Europe and North America. These losses highlight the potential risk to our agricultural systems that could result from loss of pollination. These losses include direct economic repercussions to multiple industries (beekeeping, fruit, vegetable, forage seed, oil seed and biofuel crops), and corresponding threats to human nutrition. Reasons for the losses are varied but include a lack of diverse nectar and pollen resources within intensively farmed agricultural landscapes. Focusing primarily on Europe and the USA, we review the potential approaches to provide and maintain diverse floral resources for honey bees, giving particular consideration to herbaceous plants ("forbs"). These approaches include the cultivation and maintenance of "bee pastures", consisting of diverse native or non-native flower-rich plantings maintained in fallow areas, field margins, and conservation buffer strips to sustain bee populations, support honey bee health, and aid beekeeping activities. Within this review we examine specific governmental policy initiatives to support these efforts in the USA and Europe.
\end{abstract}

\section{beekeeping / Apis mellifera / flower resources / agricultural landscapes / environmental policy}

\section{INTRODUCTION}

The biodiversity and populations of insect pollinators are in decline (Steffan-Dewenter et al., 2005; Biesmeijer et al., 2006; Goulson et al., 2008; Freitas et al., 2009). Honeybees (Apis mellifera L.,) are the most widely used pollinators of crop monocultures worldwide (Watanabe, 1994). A drastic population decline of honey bees is a serious threat to the stability and yield of food crops (Kevan and Phillips, 2001; Aizen and Harder, 2009). Yields of some fruit, seed and nut crops decrease by more than $90 \%$ without pollinators (Klein et al., 2007). Honey bees have suffered severe losses particularly since 2006-2007 in

Corresponding author: N. Desneux, nicolas.desneux@sophia.inra.fr

* Manuscript editor: Yves Le Conte the USA when an event called colony collapse disorder (CCD) was first described (Oldroyd, 2007). Many European beekeepers and researchers also have documented serious losses of honey bee colonies since the mid 1990s (Williams and Christian, 1991; Watanabe, 1994; Kearns et al., 1998). Colony losses are likely due to multiple effects (Oldroyd, 2007), and most research has focused on epidemiological factors affecting honey bee health (Cox-Foster et al., 2007; Johnson et al., 2009; Le Conte et al., 2010). However two environmental factors potentially contribute to these losses: the degradation and fragmentation of habitats for bees (Richards, 2001; Kremen et al., 2002; Larsen et al., 2005) and the negative effects of agricultural pesticides (Kevan, 1977; Desneux et al., 2007; Johnson et al., 2010). Considering the former, intensively managed agricultural landscapes 
that lack or contain only poor quality floral resources provide marginal support, if any, to managed bee populations (Maurizio, 1950; Mattila and Otis, 2006). Healthy honey bee populations and profitable beekeeping practices depend therefore on landscapes with ample and nutritious sources of pollen and nectar yielding flowers.

It is clear that adequate nectar and pollen resources are critical in maintaining honey bee health (Haydak, 1970; Michener, 2007). A deficiency in quantity and quality of pollen and nectar can lead to demographic decrease of the colony; pollen deficiency leads to low colony populations, which in turn further reduces the number of bees available to collect pollen and nectar (Keller et al., 2005). Moreover, recent work shows the importance of pollen quality and diversity on the immune response of honey bees (Alaux et al., 2010). The role of these two nutrients is so critical that beekeepers often must provide supplements in the form of sugar syrup or pollen supplement to prevent nutritional deficiency and colony failure. However, pollen supplements and syrup do not provide the same nutritive quality as natural pollen and nectar (Pedersen and Omholt, 1993).

This nutritional demand could be supplemented by crop producers and rural landowners through the protection and enhancement of additional flower resources in non-cropped areas (Murray et al., 2009). Using examples from Europe and the USA, we review the potential floral resources for honey bees at the landscape scale, particularly in noncropped agricultural landscapes. We focus on forbs because although ligneous plants (e.g., hedgerows and forests) can provide honey bees with significant food resources, their management is very specific (e.g. Fussell and Corbet, 1991; Corbet, 1995) and should be the subject of another review. Also, even though we primarily focus on the honey bee, we also discuss studies that assessed the influence of agro-environmental measures on the whole community of bees (i.e. Apiformes species). Favourable measures intended to enhance and/or sustain nectar and pollen resources for the wild bees likely also benefit the honey bee (but the opposite is not nec- essarily true). In this review, we (i) provide a general picture of the various non-cropped farmlands that could benefit honey bee health, and (ii) describe current governmental policies for promoting flowering areas within agricultural landscapes to benefit pollinators, including honey bees. We also describe some tangible agro-environmental steps that could protect floral resources, benefiting the beekeeping industry.

\section{ARABLE FARMLANDS}

\subsection{Annual cropping systems}

In annual cropping systems, the simplification of crop rotations has resulted in vast monocultures, reduced plant diversity, and large expanses of wind-pollinated or self-pollinated crops (Banaszak, 1995; Steffan-Dewenter and Tscharntke, 1999; Steffan-Dewenter et al., 2002). Where beepollinated crops are cultivated, they may provide a narrow window of abundant bloom proceed and followed by a dearth of pollen and nectar resources. For example in Europe, mass flowering crops are often limited to sunflower and oilseed rape at large landscape scales. Nectar and pollen resources are therefore abundant but only for a relatively short duration.

In addition to limited bloom time, beepollinated annual crops may be less prolific nectar plants and may be suboptimal sources of pollen. As a result, such bee dependent crops may not be fully compatible with maintaining hive populations and optimising beekeeping profits (Maurizio, 1950; Mattila and Otis, 2006).

The flora present in non-cropped areas (see Sect. 3) could provide supplemental forage resources between the bloom time of cultivated plants. However, non-cropped areas are often scarce in the most intensively farmed regions. This temporal void could be partially filled simply through the creation and protection of additional non-cropped areas. Indeed, large strips (6-12 $\mathrm{m}$ in width) of native or nonnative melliferous plants maintained between crop fields ("bee pastures") can help support 
pollinators in agricultural landscapes. Similarly herbicide mitigation efforts within cropping systems have been shown to support bees through the increase of flowering weeds adjacent to crop areas (Hald, 1999; Kleijn et al., 2006). For example, with its corresponding lack of broadleaf herbicide use, organic farming could have a positive impact on bee diversity in wheat fields (Holzschuh et al., 2007).

\subsection{Cover crops}

Cover crops are annual or perennial plants temporarily sown to protect fallow ground from erosion, reduce weed encroachment, disrupt crop pest life cycles by replacing their host plants, and most commonly to improve soil fertility by adding nitrogen and organic matter to the soil, or to reduce nitrogen runoff in water (Nearing et al., 2005; Meisinger et al., 1991; Justes et al., 2004). Some plants sown as cover crops have short, rapid flowering life cycles capable of providing early honey bee forage in the spring when they are planted in rotation before the primary crop is sown. Similarly, these plants can follow the primary crop in rotation in the fall to provide late season bee forage. Among the potentially suitable plants for this purpose are scorpionweeds (Phacelia spp.), annual clovers (Trifolium spp.), and Brassicaceae like radishes (Raphanus spp.) and mustards (Brassica spp.).

In other systems longer-lived or even perennial cover crop plants are preferred. For example a cover crop rotation between two gramineae crops such as barley and corn might be as long as 9 months (Le Roux et al., 2008).

Given the cost of seed and investment of farmer time, labor, and equipment, it is likely that justifications beyond simply supporting regional apiculture are necessary to convince farmers to plant melliferous cover crops (Critchley and Fowbert, 2000). It is therefore important to stress the primary benefits of cover cropping systems, most notably the use of legumes to fix atmospheric nitrogen reducing the need for synthetic fertilizers (Mary et al., 1999; Thönnissen et al., 2000; Justes et al., 2001).

\subsection{Perennial cropping systems}

Perennial crops, particularly in the family Rosaceae (e.g. genus Prunus, Pyrus, Malus, Rubus). are widely visited by bees. Perennial crops create favorable landscapes for honey bees in two ways: (i) the production of numerous fruits and vegetables depends on pollination by bees (Free, 1993; Klein et al., 2007) and thus farmers are concerned about the presence of sufficient bees; and (ii) the long term management of flowering cover crops can be incorporated between rows or as orchard understory plantings (USDA National Agroforestry Center, 2006).

For example, among the first landowners to take advantage of new pollinator-focused setaside programs in the US were perennial fruit growers. Their conservation efforts typically consist of planting flowering hedgerows, vegetative strips surrounding field margins, and flowering meadows, and designated bee pastures. In many instances these set-asides are intended to serve multiple functions including providing supplemental forage for bees while crops are not in bloom, as well as erosion reduction, buffers against pesticide drift, and vegetative cover for other wildlife (Vaughan and Skinner, 2008). Herbaceous ground covers in orchards, for example with Trifolium spp., provide nectar and pollen resources for honey bees.

Despite the benefit to honey bees, the presence of such flowers in orchards poses a risk of insecticide exposure to bees foraging in the area when the crop is sprayed outside of its bloom period. Therefore the incorporation of supplemental nectar and pollen plants in perennial crops must be accompanied by supplemental pesticide mitigation strategies.

\subsection{Grasslands and hay fields}

The agricultural practices necessary to maintain grasslands and hay fields often result in a decline of melliferous plants, and a corresponding reduction of honey production (Ockinger and Smith, 2007).

Grassland management practices common to Europe and the USA that reduce floral diversity were described by Plantureux et al. (2005). 
First, the historic increase of cereal silage for milk production has reduced the overall agricultural area maintained as hay fields. Second, hay fields are sown primarily with grasses, providing no resources for bees. Third, frequency of mowing further reduces the floral resources.

One country, Switzerland, has responded to the threat that grassland management practices pose to floral diversity, and hence to the entomofauna, by recommending late mowing and subsidising floral fallow land (Holzgang et al., 2002, 2005; Albrecht et al., 2007; Aschwanden et al., 2007).

\section{NON-CROPPED FARMLANDS}

Natural and semi-natural habitats provide foraging areas for bees (Lagerhöf et al., 1992; Carreck and Williams, 1997). Corbet (1995) defined such land as: field margins (strips bordering crop fields), hedgerows (linear scrub along field boundaries), woodlands, ponds, ditches and fallow farm fields. Because such habitats experience less-disturbance than cultivated fields, they help maintain overall biodiversity by buffering temporal variation in resources (Fussell and Corbet, 1991; Corbet, 1995; Dover et al., 2000; Holland and Fahrig, 2000; Ricketts et al., 2008).

In addition to honey bees, flowering plants in non-cropped farmland and their formal conservation through agri-environment schemes (AES) (Whittingham, 2007) can help restore and increase habitat for non-managed wild pollinators (Fussel and Corbet, 1992; Lagerhöf et al., 1992; Lagerhöf and Wallin, 1993; Corbet, 1995).

Two general approaches are taken to enhance floral diversity in non-cropped areas: (i) support the natural regeneration of native wildflowers, or (ii) sow varied mixtures of annual or perennial flowering plant species. We describe below the case of fallow areas and field margins, and discuss potential plants used in these areas as well as farm practices that may support honey bees.

\subsection{Fallow areas}

One important change in arable land management has been the introduction of fallow land into crop rotation (Critchley and Fowbert, 2000). Nearly 20 years ago, the practice of integrating farmland set-asides (fallows) into crop rotation plans was encouraged or mandated through national agricultural policies in many countries. Fallow-specific policies were created in EU with the reform of the common agricultural policy (CAP) in the 1980s through initiatives such as the new Agri-Environment Regulation (Pienkowski and Pain, 1997), and initially in the USA with the creation of the Conservation Reserve Program (CRP) in 1985 (Dunn et al., 1993).

The initial purpose of fallow-specific policies was to reduce surplus food production (mainly of cereals, oilseeds and protein crops; Cain and Lovejoy, 2004), and consequently incentive payments were offered to farmers as compensation for removing some of their land from production. While fallows were initially designed primarily to reduce food production, government programs supporting them have since expanded to meet other objectives such as the protection of erodible soils, maintaining water quality, and the conservation of biodiversity (Firbank et al., 1994; Dunn et al., 1993). For example, in the USA, under the CRP program, participating farmers are paid an annual rental payment for the conversion of highly erodible farmland to a less intensive use such as planting it in a mixture of native grass and wildflower species (CEC, 2006; Whittingham, 2007).

In both the USA and Europe enrollment in set-aside programs is capped at national limits, with CRP in the US currently restricted to 15.8 million ha (approximately 39 million acres) nationwide, and 2.8 million ha of setasides in the EU.

Similarly, both the EU and USA have developed technical standards for the management of set-asides (e.g. to protect water quality and biodiversity), and the allowable uses of the lands enrolled in their respective programs (e.g. such as hunting). For example, in the EU national standards establish which plants are allowed to be grown on set-asides 
and the minimum size of the set-aside area (Yliskyla-Peuralahti, 2003). Similarly in the US, while initial management standards for CRP land permitted the use of non-native vegetation and in many cases predominantly grass-based plantings, the USA Department of Agriculture (USDA) has increasingly emphasized the use of native plants which benefit a greater diversity of wildlife species (Flowers, 2003), partially as a result of efforts by national hunting organizations such as Pheasants Forever.

Such advocacy pressures in France have also helped to strengthen the biodiversity emphasis of set-aside programs, specifically hunting-related activities that are supported by a strong environmental framework. This has led to the development of diverse fallow lands that also benefit beekeepers (Decourtye et al., 2007).

This increasing emphasis on biodiversity conservation in set-aside programs has now evolved in the USA to specifically support crop pollinators. The 2008 Farm Bill, an omnibus piece of legislation passed approximately every 5 years, for the first time established pollinator conservation as a national priority for the USDA. This policy is the result of the highly publicized honey bee CCD phenomenon, as well as a report published by the National Academy of Sciences titled Status of Pollinators in North America which documented the decline of both managed and wild bee species (National Research Council, 2007). While the Farm Bill emphasizes research funding for honey bees, habitat conservation for native bee species is also mandated through the use of farmland set-aside programs like CRP, the Environmental Quality Incentives Program (EQIP), the Wildlife Habitat Incentives Program (WHIP), and the Conservation Stewardship Program (CSP), all of which are administered by the USDA's Natural Resources Conservation Service (NRCS). To implement this policy the NRCS is now required to consider pollinators in the development of land management standards for farms enrolled in USDA conservation programs, and to prioritize pollinator conservation projects when determining payment rates to partici- pating farmers (Mader, 2008; Vaughan and Skinner, 2008).

Little research supporting the specific value of these land set-aside programs to honey bees has been conducted. However, one recent study compared the development of honey bee colonies positioned near flowering fallow areas to colonies not benefiting from flowering fallows. For colonies harvesting the food resources on the fallow areas, colony weight and brood areas decreased less during the season than colonies without access to fallows, while no significant effect was found with regard to the landscape and region factors (Decourtye et al., 2008). A more complete knowledge of the influence of flowering non-cropped areas on beekeeping requires additional large-scale studies on the effects on honey production.

\subsection{Field margins}

The term "field margins" refers to strips of land along the borders of crop fields. Field margins also include vegetative strips adjacent to roads, paths, railways, hedgerows and forest boundaries. Such areas can serve a variety of agro-environmental purposes, including riparian area stabilization, soil capture via grassed waterways and buffer zones for pesticide drift.

Field margins represent a large and important global surface area and simple management modifications could provide critical ecological and environmental services, including the availability of food for honey bees. Indeed, in the USA active management of field margins for erosion control has been historically supported in NRCS programs. These same programs are now adapting management standards to incorporate forage for pollinators as a secondary benefit (Vaughan and Skinner, 2008).

Active management of field margins is also supported in Europe through the 1999 CAP reform, which offers financial rewards to farmers in compliance with environmental standards. As part of these standards, strips must occupy a minimum total surface area equal to $3 \%$ of the subsidized crop area for cereals, oilseed, proteinacous crops, linen, hemp and set-asides. 
Finally, field margins could be sown with melliferous plant species in the same way as set-aside programs like CAP/CRP. Indeed this is already happening through programs like EQIP and WHIP in the USA (Vaughan and Skinner, 2008). Taken together, such narrow strips amount to thousands of currently unexploited hectares.

As with orchard ground covers, efforts must be taken to reduce harm from insecticides to pollinators foraging in field margins. To address this concern in the USA, NRCS guidelines recommend specific efforts to reduce insecticide drift into field margins maintained for pollinators. These recommendations include night-time spraying, avoiding insecticide applications during temperature inversions (when drift potential is increased), using insecticide formulations of low toxicity to bees, and adjustment of insecticide application equipment reduce movement of insecticides outside of cropped areas (Vaughan et al., 2009).

\subsection{Rural roadsides}

Roadside verges represent another opportunity to provide pollen and nectar resources for managed honey bees and wild pollinators. In the USA alone roadside verges cover more than 4 million hectares (10 million acres) (Forman et al., 2003). Also in the USA, efforts by non-governmental conservation organizations are underway to promote roadside plantings for pollinators to the regulatory agencies that manage them (Hopwood, 2010).

Recent research has demonstrated that roadsides planted with native wildflowers support more abundant and species-rich bee communities than roadsides dominated by nonnative grasses and flowers (Hopwood, 2008). Other research demonstrates the value of roadside vegetation specifically for bumble bee nest sites (Way, 1977).

While research has not been conducted specifically on traffic-related bee mortality, observations of road crossings by butterflies in the USA revealed a mortality rate of only $2.8 \%$. The same researchers also demonstrated that where flower-rich roadside vegetation oc- curs, butterflies are less likely to leave those verge areas (Ries et al., 2001).

\subsection{Plant selection}

The value of non-cropped farmland for honey bees is very much dependent on the plant species available to them (Carreck and Williams, 1997; Cheesman, 1998). We find two main strategies to improve the availability of trophic resources for honey bees: the sowing of plants that provide beneficial resources for bees and the conservation of the native plants. If we first consider plants sown by farmers, in absence of statutory requirements for managing their non-cropped farmlands toward increased floral diversity, farmers often choose the cheapest seed, such as grasses available to meet their primary objectives, typically the protection of water quality and the reduction of soil erosion (Lacas et al., 2005). Indeed, in Europe, rye-grasses (Lolium spp.) are currently the dominant plant cover in non-cropped farmlands. But rye-grasses provide little value to bees, producing no nectar. In contrast, some species favorable for honey bee forage in Europe are reported in Table I. For comparison, Table II includes a list of plant species currently being recommended for managed and wild pollinator conservation efforts in the state of Illinois, USA.

Some studies report that Fabaceae plants (legumes) are among the most frequently visited plant families by many bee species for pollen and nectar (Lagerhöf et al., 1992; Lagerhöf and Wallin, 1993). Some legumes that are highly attractive to honey bees are pluri-annual and thus have a long flowering period (e.g., Melilotus alba, Onobrychis sativa, Medicago spp., Lotus corniculatus, Dalea purpurea). In a comparative study, field margins sown with seed mixtures of nectar- and pollenproducing legumes provided bumble bees with higher quality foraging areas than field margins sown with grass plants (Carvell et al., 2007).

Despite these reported benefits, the slow growth of some legumes may be a limiting factor in some cases. For example, beekeepers are sometimes disappointed after sowing 
A. Decourtye et al.

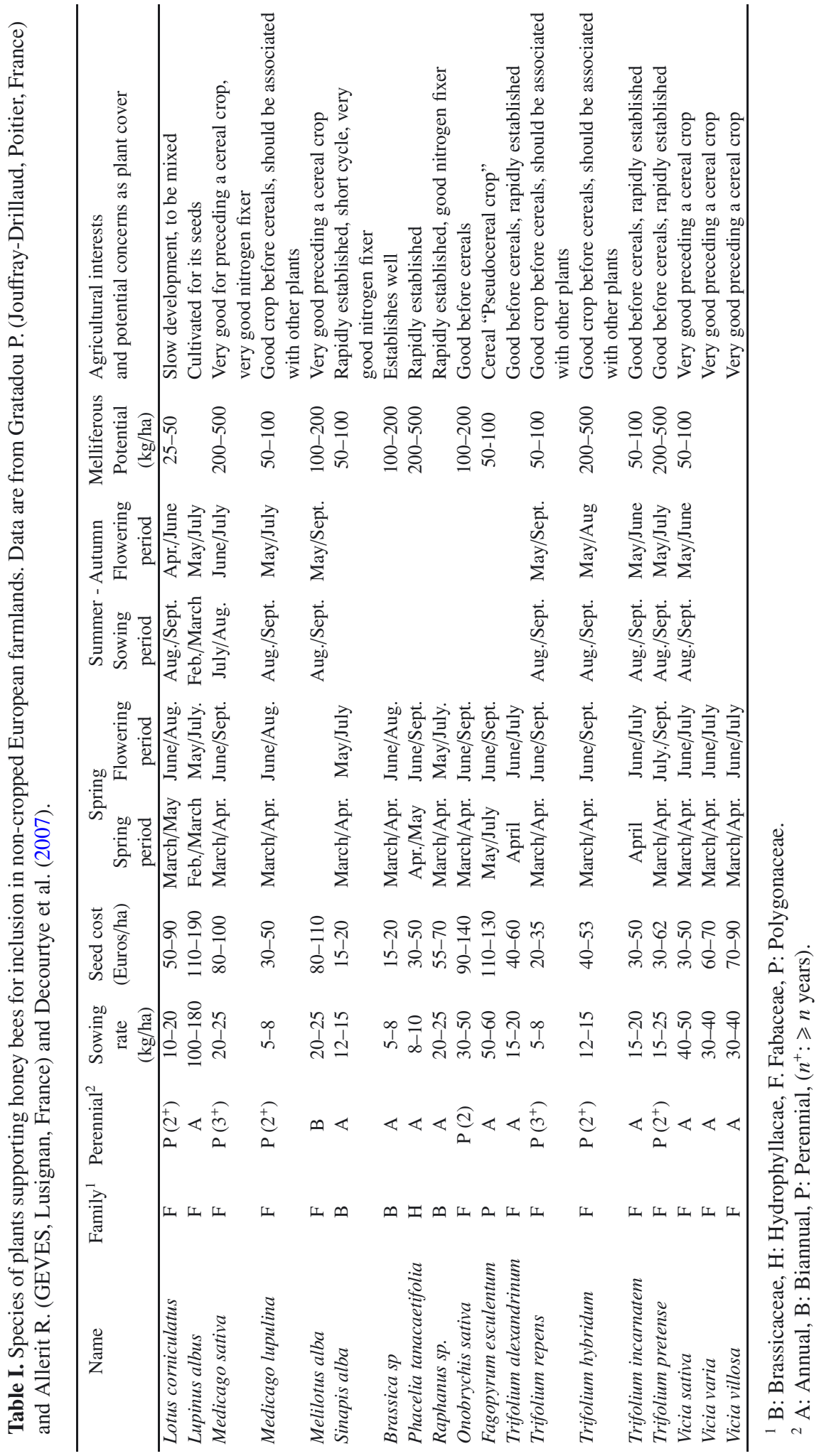




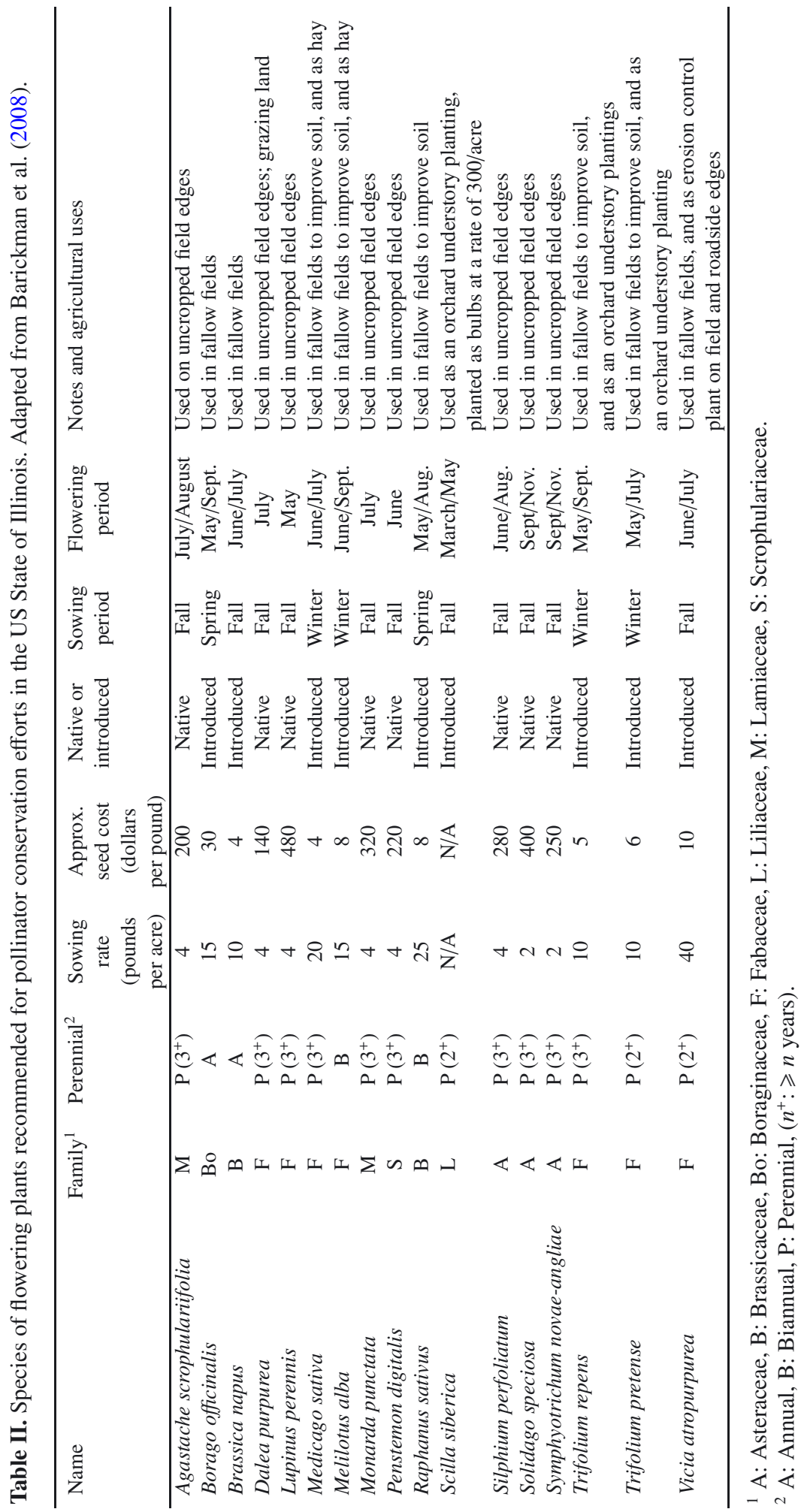


legumes because of an absence of flowers the first year. In designated bee pastures such concerns might be addressed with a mixture of annual, biannual and perennial plant species to promote early and extended flowering.

In France, the reintroduction of legumes has been recently initiated in set-asides and field margins, notably alongside rivers. These legumes, at least in combination with other species, have the potential to provide benefits to honey bees while remaining compatible with other vegetation management goals (Corre-Hellou et al., 2006). For example, Trifolium repens associates well with erosion controlling grasses like Festuca pratensis.

Despite the long-term value of perennial legumes to honey bees (Trifolium repens remains in fields for 5-6 years), farmers often prefer annual species for fallow areas due to their low cost, and non-persistent nature in cultivated fields. While some annual species may embellish the landscape with colourful and abundant flowers (e.g. Centaurea spp., Cosmos spp., Eschscholtzia spp.), they may be of little value to honey bees. Furthermore, such exotic plants can be invasive and can be in competition with the other native plants, impoverishing plant biodiversity. Conversely, other annual species that are of value to honey bees, including Sinapis alba, Borago officinalis, Fagopyrum esculentum could be incorporated into such plantings (Williams and Christian, 1991; Carreck et al., 1999; Carreck and Williams, 2002).

Finally, it is worth noting that while legumes are important pollen and nectar sources for some wild bee taxa; e.g., megachilids, eucerines or anthophorines, other bees such as andrenids, colletids or halictids, and many pollen-specialist megachilids, may not benefit from legume-rich plantings (Rasmont and Mersch, 1988). In response to the specialized requirements of wild bees, the sowing of more diverse wildflower mixtures has been promoted by advocacy groups in the UK, and in the USA by the Xerces Society for Invertebrate Conservation (Game Conservancy 1994; Corbet, 1995). These actions are based on the numerous studies demonstrating the attractiveness of perennial wildflowers for bees and wild insects in gen- eral, and their positive effects when sown in field margins (Meek et al., 2002; Carvell et al., 2004; Pywell et al., 2005). Despite these benefits, the use of native wildflowers may be limited by the high seed cost of species, lack of propagation knowledge, and the risk of introducing non-local eco-type seed sources.

\subsection{Farm practices}

In addition to plant diversity, land management practices in non-cropped areas directly impact potential honey bee (and other pollinator) abundance. Of particular importance is the need to limit chemical and mechanical destruction of non-crop floral resources, and to protect bee foraging areas from pesticide drift (Freemark and Boutin, 1995; Longley and Sotherton, 1997).

Chemical threats may come in multiple forms. For example, in addition to insecticides that may have lethal or sublethal effects on bees (Kevan, 1977; Desneux et al., 2007; Decourtye and Devillers, 2010), herbicide drift from adjacent fields may reduce floral density and diversity (Longley and Sotherton, 1997; Hald, 1999).

Mechanical destruction of melliferous plants during flowering increases mortality rates among honey bee foragers (Fluri and Frick, 2002). In addition, work by Fussel and Corbet (1992) and Corbet et al. (1991) showed that mowing limitations on plants in non-cropped is beneficial to bee populations. Kleijn et al. (2006) showed that delaying the first cutting of vegetation in fields resulted in more flowering plants, and therefore more flower-visiting insects such as honey bees. Conservation measures for pollinators in England and Sweden include restrictions on cutting plant covers (Freemark and Boutin, 1995). Similarly, late cuttings at the end of summer or in autumn are used in conservation actions of grasslands of the French Eastern regions (Malraux and Parguel, 2007).

\section{CONCLUSION}

There is clear evidence that, in concert with epidemiological threats (Cox-Foster 
et al., 2007; Johnson et al., 2009; Le Conte et al., 2010), agricultural intensification has a detrimental effect on modern apiculture (Maurizio, 1950; Kevan, 1977; Mattila and Otis, 2006; Desneux et al., 2007; Johnson et al., 2010). This trend is particularly visible in Western countries, where farmers have widely embraced agrochemicals, and maximized cultivation of arable lands. Indeed, the two principle characteristics of agricultural intensification across all global landscapes are the increased reliance upon pesticides and the reduction of biodiversity (including floral diversity). The result is a shift from heterogeneous habitats to more homogeneous ones.

There are now regional pollinator initiatives, along with regional and national conservation legislation, that can impact on the conservation of pollinators (Byrne and Fitzpatrick, 2009). As management standards for non-cropped agricultural set-asides, are adapted to support pollinators, including honey bees, one important goal should be to temporally and spatially increase heterogeneous habitats. To this end, it is first urgent to preserve current semi-natural habitats adjacent to farmlands. In addition, policies requiring the management of non-cropped farmland to increase floral diversity and abundance are essential (especially in intensively farmed areas). Such policies will not only sustain managed beekeeping, but crop production through enhanced pollination services, and support biodiversity in general (e.g. birds and mammals). This enhanced biodiversity in turn provides other human benefits such as supporting outdoor recreation, agro-tourism, and landscape aesthetics.

\section{ACKNOWLEDGEMENTS}

We thank Marla Spivak for helpful comments on an earlier version of the manuscript. This work was supported in part by a grant from French Ministry of Agriculture (CASDAR).

Aménagement du paysage en vue d'améliorer les ressources florales pour les abeilles dans les agrosystèmes. apiculture / Apis mellifera / ressources florales / paysage agricole / politique environnementale

Zusammenfassung - Verbesserung im Angebot der Nahrungspflanzen für Honigbienen in landwirtschaftlichen Ökosystemen. Intensiv genutzte Agrarlandschaften, denen Blütenpflanzen fehlen, oder die nur minderwertige Nahrungspflanzen aufweisen, können imkerlich genutzte Honigbienenvölker nur mit Mühe ernähren. Ein Mangel an Menge und Qualität von Pollen und Nektar kann zu einer Schwächung des Bienenvolks führen, da eine angemessene Nektar- und Pollenversorgung entscheidend für den Erhalt der Bienengesundheit sind. Daher sind gesunde Bienenvölker und eine wirtschaftliche Imkerei auf Landschaften mit reichhaltigen und nährstoffreichen Pollenquellen und nektarspendenden Blüten angewiesen. Anhand von Beispielen aus Europa und den USA geben wir einen Überblick über mögliche Nahrungsquellen für Honigbienen im Landschaftsraum, mit besonderer Berücksichtigung von nicht kultivierten Flächen in der Agrarlandschaft. Wir beschreiben einige konkrete landwirtschaftliche Umweltmaßnahmen, die den Blütenreichtum verbessern und so der Bienenhaltung nützen könnten. Die in den nicht kultivierten Flächen (Feldränder, Hecken, Gehölze, Teiche, Gräben, Brachen) vorhandene Flora könnte zwischen den Blühzeiten der angebauten Pflanzen den Bienen ergänzende Nahrung bieten. Die bereits vorhandenen, an Ackerland angrenzenden naturnahen Habitate sollten daher dringend erhalten werden. Solche unkultivierten Flächen sind in den am intensivsten genutzten Agrarlandschaften jedoch oft selten. Diese Lücke könnte durch die Schaffung und den Schutz von zusätzlichen nicht kultivierten Flächen gefüllt werden. Als Maßnahme zur Erhaltung von Bestäubern in landwirtschaftlich genutzten $\mathrm{Ge}$ bieten wurde die Anlage von ausgedehnten Streifen mit Nektarpflanzen zwischen den Anbaufeldern empfohlen. Gleichermaßen konnte gezeigt werden, dass die Reduzierung des Herbizideinsatzes in Anbauflächen für Bienen günstig ist, weil blühende Unkräuter neben den Äckern dadurch zunehmen. Darüberhinaus haben einige Pflanzen, die als Deckfrucht eingesetzt werden, kurze Entwicklungszeiten mit früher Blüte, und sind daher in der Lage, den Bienen früh Nahrung zu bieten, wenn sie abwechselnd mit, bzw. vor der Hauptertragspflanze gesät werden (Phazelie, einjährige Kleearten, Radieschen, Senf).

Neben der regionalen und nationalen Gesetzgebung können regionale Bestäuberinitiativen die Erhaltung der Bestäuber fördern. Ein bedeutendes Ziel bei der Entwicklung von Standards für unbebautes Ackerland zum Erhalt von Bestäubern, einschließlich der Honigbiene, sollte es sein, zeitlich und räumlich heterogene Habitate zu vermehren. Die Schaffung von Richtlinien, die eine 
Bewirtschaftung von unkultivierten Flächen zur Vermehrung des Blütenreichtums und der Vielfalt vorschreiben, ist von entscheidender Bedeutung (besonders in intensiv bebauten Ackergebieten). Diese Maßnahmen bestehen typischerweise im Pflanzen von blühenden Hecken, Randstreifen um Felder, und blühenden Wiesen. Zwei verschiedene Vorgehensweisen sind üblich, um die Blütenvielfalt in unbebauten Flächen zu erhöhen: (i) die Unterstützung der natürlichen Regeneration der einheimischen Wildblumen, oder (ii) das Einsäen von verschiedenen Mischungen einjähriger oder mehrjähriger Pflanzen. Solche Richtlinien werden nicht nur die Bienenhaltung unterstützen, sondern durch verbesserte Bestäubung auch die Ernteerträge erhöhen, sowie die Biodiversität im Allgemeinen fördern (z.B. Vögel und Säugetiere).

\section{Bienenhaltung / Apis mellifera / Nahrungspflan- zen / Agrarlandschaften / Umweltrichtlinie}

\section{REFERENCES}

Aizen M.A., Harder L.D. (2009) The global stock of domesticated honey bees is growing slower than agricultural demand for pollination, Curr. Biol. 19, 915-918.

Alaux C., Ducloz F., Crauser D., Le Conte Y. (2010) Diet effects on honeybee immunocompetence, Biol. Lett., DOI:10.1098/rsbl.2009.0986.

Albrecht M., Duelli P., Müller C., Kleijn D., Schmid B. (2007) The Swiss agri-environment scheme enhances pollinator diversity and plant reproductive success in nearby intensively managed farmland, J. Appl. Ecol. 44, 813-822.

Aschwanden J., Holzgang O., Jenni L. (2007) Importance of ecological compensation areas for small mammals in intensively farmed areas, Wildl. Biol. 13, 150-158.

Banaszak J. (1995) Changes in fauna of wild bees in Europe, Pedagogical University, Bydgoszcz, Poland.

Barickman G., Vaughan M., Mader E. (2008) Pollinator Biology and Habitat, Illinois Biology Technical Note No. 23, Illinois NRCS, USA.

Biesmeijer J.C., Roberts S.P.M., Reemer M., Ohlemueller R., Edwards M., Peeters T., Schaffers A.P., Potts S.G., Kleukers R., Thomas C.D., Settele J., Kunin W.E. (2006) Parallel declines in pollinators and insect-pollinated plants in Britain and the Netherlands, Science 313, 351-354.

Byrne A., Fitzpatrick U. (2009) Bee conservation policy at the global, regional and national levels, Apidologie 40, 194-210.

Cain Z., Lovejoy S. (2004) History and Outlook for Farm Bill Conservation Programs, Choices: The Magazine of Food, Farm, and Resource Issues 4, $37-42$.
Carreck N.L., Williams I.H. (1997) Observations on two commercial flower mixtures as food sources for beneficial insects in the UK, J. Agric. Sci. Camb. 128, 397-403.

Carreck N.L.,Williams I.H. (2002) Food for insect pollinators on farmland: insect visits to flowers of annual seed mixtures, J. Insect Conserv. 6, 13-23.

Carreck N.L., Williams I.H., Oakley J.N. (1999) Enhancing farmland for insect pollinators using flower mixtures, Aspect. Appl. Biol. 54, 101-108.

Carvell C., Meek W.R., Pywell R.F., Goulson D., Nowakowski M. (2007) Comparing the efficiency of agri-environment schemes to enhance bumble bee abundance and diversity on arable field margins, J. Appl. Ecol. 44, 29-40.

Carvell C., Meek W.R., Pywell R.F., Nowakowski M. (2004) The response of bumblebees to successional change in newly created arable field margins, Biol. Conserv. 118, 327-339.

CEC (2006) Communication from the Commission, Halting the loss of biodiversity by 2010 and beyond: sustaining ecosystem services for human bell-being, Commission of the European Communities, Brussels, Belgium.

Cheesman O.D. (1998) The impact of some field boundary management practices on the development of Dipsacus fullonum L. flowering stems, and implications for conservation, Agric. Ecosyst. Environ. 68, 41-49.

Corbet S.A. (1995) Insects, plants and succession: advantages of long-term set-aside, Agric. Ecosyst. Environ. 55, 61-67.

Corbet S.A., Williams I.H., Osborne J.L. (1991) Bees and the pollination of crops and wild flowers in the European community, Bee World 71, 47-59.

Corre-Hellou G., Fustec J., Crozat Y. (2006) Interspecific competition for soil $\mathrm{N}$ and its interaction with $\mathrm{N}_{2}$ fixation, leaf expansion and crop growth in pea-barley intercrops, Plant Soil 282, 195-208.

Cox-Foster D.L., Conlan S., Holmes E.C., Palacios G., Evans J.D., Moran N.A., Quan P.L., Briese T., Hornig M., Geiser D.M., Martinson V., vanEngelsdorp D., Kalkstein A.L., Drysdale A., Hui J., Zhai J., Cui L., Hutchison S.K., Simons J.F., Egholm M., Pettis J.S., Lipkin W.I. (2007) A metagenomic survey of microbes in honey bee colony collapse disorder, Science 318, 283-287.

Critchley C.N.R., Fowbert J.A. (2000) Development of vegetation on set-aside land for up to nine years from a national perspective, Agric. Ecosyst. Environ. 79, 159-174.

Decourtye A., Devillers J. (2010) Ecotoxicology of neonicotinoids insecticides in the bees, in: Thany S. (Ed.), Insect Nicotinic Acetylcholine Receptors, Landes Bioscience.

Decourtye A., Lecompte P., Pierre J., Chauzat M.P., Thiébeau P. (2007) Introduction de jachères florales en zones de grandes cultures - ou comment 
mieux concilier agriculture et biodiversité, et par conséquent, l'apiculture, Le Courrier de l'Environnement de l'INRA 54, 33-56.

Decourtye A., Odoux J.-F., Cluzeau-Moulay S. (2008) Influence des aménagements floristiques sur les abeilles, Bull. Tech. Apic. 35, 114-123.

Desneux N., Decourtye A., Delpuech J.M. (2007) The sublethal effects of pesticides on beneficial arthropods, Annu. Rev. Entomol. 52, 81-106.

Dover J., Sparks T., Clarke S., Gobbett K., Glossop S. (2000) Linear features and butterflies: the importance of green lanes, Agric. Ecosyst. Environ. 80, 227-242.

Dunn C.P., Stearns F., Guntenspergen G.R., Sharpe D.M. (1993) Ecological benefits of the conservation reserve program, Conserv. Biol. 7, 132-139.

Firbank L.G., Telfer M.G., Eversham B.C., Arnold H.R. (1994) The use of species-decline statistics to help target conservation policy for set-aside arable land, J. Environ. Manage. 42, 415-422.

Flowers T.L. (2003) CRP Grass Mixtures. Why? USDA-Natural Resources Conservation Service (NRCS), Meade, Kansas, USA.

Fluri P., Frick R. (2002) Honey bee losses during mowing of flowering fields, Bee World 83, 109-118.

Forman R.T., Sperling D., Bissonette J.A., Clevenger A.P., Cutshall C.D., Dale V.H., Fahrig L., France R., Goldman C.R., Heanue K., Jones J.A., Swanson F.J., Turrentine T., Winter T.C. (2003) Road Ecology: Science and Solutions, Island Press, Washington, DC.

Free J.B. (1993) Insect pollination of crops, 2nd ed., Academic Press, London.

Freemark K., Boutin C. (1995) Impacts of agricultural herbicide use on terrestrial wildlife in temperate landscapes: a review with special reference to North America, Agric. Ecosyst. Environ. 52, 67-91.

Freitas B.M., Imperatriz-Fonseca V.L., Medina L.M., Kleinert A.D.P., Galetto L., Nates-Parra G., Quezada-Euan J.J.G. (2009) Diversity, threats and conservation of native bees in the Neotropics, Apidologie 40, 332-346.

Fussell M., Corbet S.A. (1991) Forage for bumble bees and honey bees in farmland: a case study, J. Apic. Res. 30, 87-97.

Fussell M., Corbet S.A. (1992) Flower usage by bumble-bees: a basis for forage plan management, J. Appl. Ecol. 29, 451-465.

Goulson D., Lye G.C., Darvill B. (2008) Decline and conservation of bumble bees, Annu. Rev. Entomol. 53, 191-208.

Hald A.B. (1999) Weed vegetation (wild flora) of long established organic versus conventional cereal fields in Denmark, Ann. Appl. Biol. 134, 307314.

Haydak M.H. (1970) Honey bee nutrition, Annu. Rev. Entomol. 15, 143-156.
Holland J., Fahrig L. (2000) Effect of woody borders on insect density and diversity in crop fields: a landscape-scale analysis, Agric. Ecosyst. Environ. $78,115-122$.

Holzschuh A., Steffan-Dewenter I., Kleijn D., Tscharntke T. (2007) Diversity of flower-visiting bees in cereal fields: effects of farming system, landscape composition and regional context, J. Appl. Ecol. 44, 41-49.

Holzgang O., Pfister H.P., Heynen D., Blant M., Righetti A., Berthoud G., Marchesi P.1, Maddalena T., Müri H., Wendelspiess M., Dändliker G., Mollet P., Bornhauser-Sieber U. (2002) Les corridors faunistiques en Suisse, Cahier de l'environnement No. 326, Office fédéral de l'environnement, des forêts et du paysage (OFEFP), Société suisse de Biologie de la Faune (SSBF), Station ornithologique suisse de Sempach, Berne, 120 p.

Holzgang O., Righetti A., Pfister H.P. (2005) Swiss wildlife corridors on paper, imagined and in the countryside, GAIA - Ecol. Perspect. Sci. Soc. 14, $148-151$.

Hopwood J.L. (2008) The contribution of roadside grassland restorations to native bee conservation, Biol. Conserv. 141, 2632-2640.

Hopwood J.L. (2010) Pollinators and Roadsides: Verge Management for Bees and utterflies, The Xerces Society Invertebrate Conservation Fact Sheet.

Johnson R.M., Ellis M.D., Mullin C.A., Frazier M. (2010) Pesticides and honey bee toxicity - USA, Apidologie 41, 312-331.

Johnson R.M., Evans J.D., Robinson G.E., Berenbaum M.R. (2009) Changes in transcript abundance relating to colony collapse disorder in honey bees (Apis mellifera), Proc. Natl. Acad. Sci. USA 106, 14790-14795.

Justes E., Thiébeau P., Cattin G., Larbre D., Nicolardot B. (2001) Libération d'azote après retournement d'une culture de luzerne: un effet sur deux campagnes, Perspectives Agricoles 264, 22-28.

Justes E., Dorsainvil F., Alexandre M., Thiébeau P. (2004) Simulation with STICS soil-crop model of catch crop effects on nitrate leaching during the fallow period and on $\mathrm{N}$ released for the succeeding main crop, in: Hatch D.R., Chadwick S.C., Jarvis J.A., Roker D.J. (Eds.), Controlling nitrogen flows and losses, Wageningen Academic Publishers, Wageningen, The Netherlands, pp. 444-446.

Kearns C.A., Inouye D.W., Waser N.M. (1998) Endangered mutualisms: the conservation of plant-pollinator interactions, Annu. Rev. Ecol. Syst. 29, 83-112.

Keller I., Fluri P., Imdorf A. (2005) Pollen nutrition and colony development in honey bees, Part II, Bee World 86, 27-34.

Kevan P.G. (1977) Blueberry crops in Nova Scotia and New Brunswick: pesticides and crop reductions, Can. J. Agr. Econ. 25, 61-64. 
Kevan P.G., Phillips T. (2001) The economics of pollinator declines: assessing the consequences, Conserv. Ecol. 5, 8.

Kleijn D., Baquero R.A., Clough Y., Diaz M., De Esteban J., Fernandez F., Gabriel D., Herzog F., Holzschuh A., Johl R., Knop E., Kruess A., Marshall E.J.P., Steffan-Dewenter I., Tscharntke T., Verhulst J., West T.M., Yela J.L. (2006) Mixed biodiversity benefits of agri-environment schemes in five European countries, Ecol. Lett. 9, 243-254.

Klein A.M., Vaissière B.E., Cane J.H., SteffanDewenter I., Cunningham S.A., Kremen C., Tscharntke T. (2007) Importance of pollinators in changing landscapes for world crops, Proc. R. Soc. Lond. B Biol. 274, 303-313.

Kremen C., Williams N.M., Thorp R.W. (2002) Crop pollination from native bees at risk from agricultural intensification, Proc. Natl. Acad. Sci. USA 99, 16812-16816.

Lacas J.G., Voltz M., Gouy V., Carluer N., Gril J.J. (2005) Using grassed strips to limit pesticide transfer to surface water: a review, Agron. Sustain. Dev. 25, 253-266.

Lagerhöf J., Wallin H. (1993) The abundance of arthropods along two field margins with different types of vegetation composition: an experimental study, Agric. Ecosyst. Environ. 43, 141-154.

Lagerhöf J., Stark J., Svensson B. (1992) Margins of agricultural field as habitats for pollinating insects, Agric. Ecosyst. Environ. 40, 117-124.

Larsen T.H., Williams N., Kremen C. (2005) Extinction order and altered community structure rapidly disrupt ecosystem functioning, Ecol. Lett. 8, 538-547.

Le Conte Y., Ellis M., Ritter W. (2010) Varroa mites and honey bee health: can Varroa explain part of the colony losses? Apidologie 41, 353-363.

Le Roux X., Barbault R., Baudry J., Burel F., Doussan I., Garnier E., Herzog F., Lavorel S., Lifran R., Roger-Estrade J., Sarthou J.P., Trommetter M. (2008) Agriculture et biodiversité - Valoriser les synergies - Synthèse du rapport d'expertise - 2ème partie, Expertise scientifique collective INRA.

Longley M., Sotherton N.W. (1997) Factors determining the effects of pesticides upon butterflies inhabiting arable farmland, Agric. Ecosyst. Environ. 61, $1-12$.

Mader E. (2008) Financial incentives for pollinator conservation, Newsletter of the Midwest Organic Tree Fruit Growers Network 3, 4-5.

Malraux J.-B., Parguel P. (2007) Préétude des relations entre la qualité des miels et pratiques herbagères en zone de production du morbier, Bull. Tech. Apic. 34, 55-67.

Mary B., Beaudoin N., Justes E., Machet J.M. (1999) Calculation of nitrogen mineralization and leaching in fallow soil using a simple dynamic model, Eur. J. Soil Sci. 50, 549-566.
Mattila H.R., Otis G.W. (2006) Influence of pollen diet in spring on development of honey bee (Hymenoptera: Apidae) colonies, J. Econ. Entomol. 99, 604-613.

Maurizio A. (1950) The influence of pollen feeding and brood rearing on the length of life and physiological condition of the honeybee, Bee World 31, 9-12.

Meek B., Loxton D., Sparks T., Pywell R., Pickett H., Nowakowski M. (2002) The effect of arable field margin composition on invertebrate biodiversity, Biol. Conserv. 106, 259-271.

Meisinger J.J., Hargrove W.L., Mikkelsen R.L., Williams J.R., Benson V.W. (1991) Effects of cover crops on groundwater quality, in: Hargrove W.L. (Ed.), Cover crops for clean water, Conservation Society, Jackson, Tennessee, USA, pp. 57-68.

Michener C.D. (2007) The bees of the world, 2nd edition, The Johns Hopkins University Press, Baltimore and London, USA and UK.

Murray T.E., Kuhlmann M., Potts S.G. (2009) Conservation ecology of bees: populations, species and communities, Apidologie 40, 211236.

National Research Council (2007) Status of pollinators in North America, The National Academies Press, Washington DC, USA.

Nearing M.A., Jetten V., Baffaut C., Cerdan O., Couturier A., Hernandez M., Le Bissonnais Y., Nichols M.H., Nunes J.P., Renschler C.S., Souchere V., van Oost K. (2005) Modelling response of soil erosion and runoff to changes in precipitation and cover, Catena 61, 131-154.

Ockinger E., Smith H.G. (2007) Semi-natural grasslands as population sources for pollinating insects in agricultural landscapes, J. Appl. Ecol. 44, 5059.

Oldroyd B.P. (2007) What's killing American honey bees? PLoS Biol. 5, 1195-1199.

Pedersen K., Omholt S.W. (1993) A comparison of diets for honeybee, Norwegian J. Agric. Sci. 7, 213 219.

Pienkowski M.W., Pain D.J. (1997) Farming and Birds in Europe: the Common Agricultural Policy and its implications for bird conservation, Academic Press, London, UK.

Plantureux S., Peeters A., Mccracken D. (2005) Biodiversity in intensive grasslands: effects of management, improvement and challenges, Agron. Res. 3, 153-164.

Pywell R.F., Warman E.A., Carvell C., Sparks T.H., Dicks L.V., Bennett D., Wright A., Critchley C.N.R., Sherwood A. (2005) Providing foraging resources for bumblebees in intensively farmed landscapes, Biol. Conserv. 121, 479-494. 
Rasmont P., Mersch P. (1988) Première estimation de la dérive faunique chez les bourdons de la Belgique (Hymenoptera: Apidae), Ann. Soc. R. Zool. Belgique, 118, 141-147.

Richards A.J. (2001) Does low biodiversity resulting from modern agricultural practice affect crop pollination and yield? Ann. Bot.-London 88, 165172.

Ricketts T.H., Regetz J., Steffan-Dewenter I., Cunningham S.A., Kremen C., Bogdanski A., Gemmill-Herren B., Greenleaf S.S., Klein A.M., Mayfield M.M., Morandin L.A., Ochieng A., Viana B.F. (2008) Landscape effects on crop pollination services: are there general patterns? Ecol. Lett. 11, 499-515.

Ries L., Debinski D.M., Wieland M.L. (2001) Conservation value of roadside prairie restoration to butterfly communities, Conserv. Biol. 15, 401411.

Steffan-Dewenter I., Munzenberg U., Burger C., Thies C., Tscharntke T. (2002) Scale-dependent effects of landscape context on three pollinator guilds, Ecology 83, 1421-1432.

Steffan-Dewenter I., Potts S.G., Packer L. (2005) Pollinator diversity and crop pollination services are at risk, Trends Ecol. Evol. 20, 1-2.

Steffan-Dewenter I., Tscharntke T. (1999) Effects of habitat isolation on pollinator communities and seed set, Oecologia 121, 432-440.

Thönnissen C., Mimore D.J., Ladha J.K., Olk D.C., Schmidhlater U. (2000) Legume decomposition and nitrogen release when applied as green manures to tropical vegetable production systems, Agron. J. 92, 253-260.
UK Game Conservancy (1994) Game and shooting crops, Game Conservancy, Fordingbridge, Hampshire, UK.

USDA National Agroforestry Center (2006) Agroforestry: Sustaining Native Bee Habitat For Crop Pollination, Agroforestry Notes, August 2006, pp. 1-4.

Vaughan M., Skinner M. (2008) Using Farm Bill Programs for Pollinator Conservation, USDANRCS National Plant Data Center, online: http:// www.xerces.org/wp-content/uploads/2008/11/ using_farm_bill_programs_xerces_society.pdf.

Vaughan M., Mader E., Norment J., Keirstead D., Alexander T., Barrett N. Schreier B., Lipsky A., Giorgi K., Henery H., Stubbs C. (2009) New England Pollinator Conservation Handbook, USDA-NRCS, online: ftp://ftp-fc.sc.egov. usda.gov/NH/WWW/Technical/New_England_ NRCS_Pollinator_Tech_Note_FINAL.pdf.

Watanabe M.E. (1994) Pollination worries rise as honey bees decline, Science 265, 1170-1170.

Way J.M. (1977) Roadside verges and conservation in Britain: a review, Biol. Conserv. 12, 65-74.

Whittingham M.J. (2007) Will agri-environment schemes deliver substantial biodiversity gain, and if not why not? J. Appl. Ecol. 44, 1-5.

Williams I.H., Christian D.G. (1991) Observations on Phacelia tanacetifolia Bentham (Hydrophyllaceae) as a food plant for honey bees and bumble bees, J. Apic. Res. 30, 3-12.

Yliskyla-Peuralahti J. (2003) Biodiversity - a new spatial challenge for Finnish agri-environmental policies? J. Rural Stud. 19, 215-231. 